\title{
Chronic Budd-Chiari syndrome due to obstruction of the intrahepatic portion of the inferior vena cava
}

\author{
D. V. DATTA, ${ }^{1}$ S. SAHA, SAMANTA A. K. Singh, B. B. GUPTA, B. K. AikAT, \\ K. S. CHUGH, AND P. N. CHHUTTANI
}

From the Division of Hepatic Diseases, Department of Medicine, Postgraduate Institute of Medical Education and Research, Chandigarh, India

SUMMARY Clinical features of obstruction of the intrahepatic portion of the inferior vena cava were observed in five out of the 11 patients with the Budd-Chiari syndrome seen during the last four years. These patients apparently formed a distinct group from the remaining six and resembled in clinical course, biochemical features, haemodynamic findings, and radiological investigations the patients described as cases of membranous obliteration of the intrahepatic portion of the inferior vena cava. The present study reports five such patients diagnosed with the help of venous catheterization, percutaneous hepatography, and haemodynamic studies. The value of distinguishing these patients from those with obstruction due to hepatic vein occlusion is highlighted because of the difference in the prognosis and treatment.

Following the initial report of Budd in 1845 and Chiari in 1899 on the occurrence of occlusion of hepatic veins, a number of reports have appeared about different aetiological factors in the genesis of this syndrome. Intraabdominal malignancies, polycythaemia, trauma, and sepsis are some of the well recognized aetiological factors (Parker, 1959). This clinical syndrome may also be due to obstruction of the inferior vena cava. With progress in the venous catheterization technique and corrective surgery, obstruction of the hepatic portion of inferior vena cava as a primary cause of the Budd-Chiari syndrome has recently been recognized (Nakamura, Nakamura, Aikawa, Suzuki, Onodera, and Karoji, 1968). The lesion in the inferior vena cava has been recorded as stenosis (Nishikawa, 1918) and membranous obstruction with or without coarctation (Bennett, 1950; Kimura Shirotani, Hirooka, Terada, Iwahashi, and Mactani, 1963). A number of reports have emphasized the frequent finding of such patients in Japan (Kimura et al, 1963; Yamamoto, Yokoyama, Takeshige, and Iwatssuki, 1968; Nakamura and coworkers, 1968). These cases were primarily diagnosed in life by venous catheterization, so demonstrating a filling defect in a small segment of

\footnotetext{
1Please request reprints from Dr D. V. Datta, Division of Hepatic Diseases, Postgraduate Institute of Medical Education and Research, Chandigarh, India.
}

Received for publication 17 February 1972. the hepatic portion of the inferior vena cava, and in a few the membrane was demonstrated at necropsy. Liver biopsy studied in these reports has shown haemorrhage in hepatic parenchyma and congestion in cases with a short illness and cirrhosis in patients with a long illness. It is important to differentiate these cases from those of the Budd-Chiari syndrome due to hepatic vein pathology as these membranous defects can be dealt with surgically (Yamamoto et al, 1968).

The present study reports similar patients diagnosed during life with the help of venous catheterization, venography, and hepatography.

\section{Material and Methods}

Patients admitted with the diagnosis of the BuddChiari syndrome in our Institute during the last four years have been analysed.

Routine liver function tests (King and Wootton, 1959), venous catheterization studies (Sherlock, 1969), splenoportograms (Atkinson and Sherlock, 1954), and hepatography (Moreno, Ruzicka, Rousselot, Burchell, Bono, Slafsky, and Burke, 1965) were carried out by standard methods. A routine chest radiograph was normal in all the patients. A localized obstruction of the intrahepatic portion of the inferior vena cava was demonstrated by simultaneously catheterizing the inferior vena cava by the cubital and femoral routes. Hepatic veins could 
not be negotiated by the cubital route on repeated attempts in any one of these patients.

\section{Results}

Table I depicts the possible aetiological factors together with the ultimate outcome in 11 patients with the Budd-Chiari syndrome. These could be divided in two types; type 1 consisted of six patients having hepatic vein obstruction without obstruction of the inferior vena cava, and of these in two the onset was in the postpartum period, two had polycythaemia, one was pregnant at the time of onset, and in one no associated aetiological factor could be traced. Type II consisted of five patients having a well defined obstruction of the intrahepatic portion of the inferior vena cava of unknown origin. Five of the six patients with hepatic vein occlusion (type I) died after two months to two years of illness and only one patient is living after an illness of seven months. In contrast, four of the five patients with the BuddChiari syndrome due to inferior vena cava obstruction (type II) are still living having been ill from three to 20 years. One patient died after being ill for 15 years.

Five patients diagnosed as obstruction of the intrahepatic portion of the inferior vena cava with the Budd-Chiari syndrome during life are reported in detail.

\section{Case Reports}

\section{CASE 1}

B.S., a 20 -year-old farmer, became ill 10 years before with pain in the right hypochondrium associated with a low-grade fever which was followed by repeated attacks of oedema and distension of the abdomen. He also had variceal bleeds one and eight

\begin{tabular}{|c|c|c|c|c|c|c|}
\hline Case No. & $\begin{array}{l}\text { Age at } \\
\text { Onset (yr) } \\
\text { and Sex }\end{array}$ & First Symptom & $\begin{array}{l}\text { Duration of } \\
\text { Illness at } \\
\text { Presentation }\end{array}$ & $\begin{array}{l}\text { Survival Period at } \\
\text { Death/Follow Up }\end{array}$ & Fate & $\begin{array}{l}\text { Possible Aetiological } \\
\text { Factor }\end{array}$ \\
\hline
\end{tabular}

With inferior vena cava obstruction

$1 \quad 10 \mathrm{M}$ Pain right

hypochondrium, ascites

$10 \mathrm{yr} \quad 15 \mathrm{yr}$

$\begin{array}{lllll}2 & 14 \mathrm{~F} & \begin{array}{l}\text { Prominent vein over } \\ \text { abdomen }\end{array} & 10 \mathrm{yr} & 11 \mathrm{yr} \\ 3 & 27 \mathrm{M} & \begin{array}{l}\text { Pain right } \\ \text { hypochondrium }\end{array} & 3 \mathrm{yr} & 4 \mathrm{yr} \\ 4 & 43 \mathrm{M} & \begin{array}{l}\text { Ascites } \\ 5\end{array} & 20 \mathrm{yr} & 20 \mathrm{yr} \\ & 45 \mathrm{M} & \begin{array}{l}\text { Ascites, prominent } \\ \text { abdominal veins }\end{array} & 2 \mathrm{yr} & 3 \mathrm{yr}\end{array}$

Without inferior vena cava obstruction

\begin{tabular}{|c|c|c|c|c|c|c|}
\hline 6 & $23 \mathrm{~F}$ & Ascites & $2 \mathrm{yr}$ & $2 \mathrm{yr}$ & $\begin{array}{l}\text { Died, hepatic coma; } \\
\text { necropsy hepatic vein }\end{array}$ & Postpartum infection \\
\hline 7 & $35 M$ & $\begin{array}{l}\text { Ascites, pain right } \\
\text { hypochondrium }\end{array}$ & $1 \mathrm{mth}$ & $2 \mathrm{mth}$ & $\begin{array}{l}\text { thrombosis } \\
\text { Died, hepatic coma; } \\
\text { biopsy hepatic vein } \\
\text { obstruction }\end{array}$ & $\begin{array}{l}\text { Polycythaemia, red cell } \\
\text { mass } 52.4 \mathrm{ml} / \mathrm{kg}^{\mathbf{1}}\end{array}$ \\
\hline 8 & $23 \mathbf{F}$ & $\begin{array}{l}\text { Ascites, pain right } \\
\text { hypochondrium }\end{array}$ & $2 \mathrm{mth}$ & $4 \mathrm{mth}$ & $\begin{array}{l}\text { Died, hepatic coma; } \\
\text { necropsy hepatic vein } \\
\text { thrombosis }\end{array}$ & Postpartum infection \\
\hline 9 & $40 \mathrm{~F}$ & $\begin{array}{l}\text { Ascites, pain right } \\
\text { hypochondrium }\end{array}$ & $8 \mathrm{mth}$ & $10 \mathrm{mth}$ & $\begin{array}{l}\text { Died, hepatic coma; } \\
\text { necropsy hepatic vein } \\
\text { thrombosis }\end{array}$ & $\begin{array}{l}\text { Polycythemia, red cell } \\
\text { mass } 54.5 \mathrm{ml} / \mathrm{kg}\end{array}$ \\
\hline 10 & $25 \mathrm{~F}$ & $\begin{array}{l}\text { Ascites, pain right } \\
\text { hypochondrium }\end{array}$ & 15 days & $4 \mathrm{mth}$ & $\begin{array}{l}\text { Died, hepatic coma; } \\
\text { necropsy hepatic vein } \\
\text { thrombosis }\end{array}$ & Pregnancy \\
\hline 11 & $40 M$ & $\begin{array}{l}\text { Pain right } \\
\text { hypochondrium, ascites }\end{array}$ & $7 \mathrm{mth}$ & $7 \mathrm{mth}$ & $\begin{array}{l}\text { Alive, persistent ascites; } \\
\text { biopsy hepatic vein } \\
\text { obstruction }\end{array}$ & Unknown \\
\hline
\end{tabular}

Died, fatal haematemesis; Membranous obstruction necropsy, membranous of inferior vena cava obstruction of hepatic portion of inferior vena cava and associated hepatoma

Alive, advised surgery; Membranous obstruction biopsy scattered haemor- of inferior vena cava rhages

Alive, advised surgery; Membranous obstruction biopsy pericentral of inferior vena cava haemorrhages

Alive, ascites relieved; Membranous obstruction biopsy changes suggestive of inferior vena cava of cirrhosis

Alive, ascites relieved, Membranous obstruction biopsy changes suggestive of inferior vena cava of cirrhosis and hepatic vein obstruction

Table I Clinical summary of patients with the Budd-Chiari syndrome 
years previously and was aware of prominent abdominal veins since that time.

Examination revealed an anaemic man with gynecomastia. The abdomen was distended and had tortuous superficial veins extending from the pelvic brim to the manubrium sterni with a flow from below upwards. The liver was palpable by $3 \mathrm{~cm}$ under the costal margin and the spleen by $4 \mathrm{~cm}$, with marked ascites. Investigations revealed mild to moderate abnormalities in liver function tests (Table II). Haemodynamic studies confirmed the BuddChiari syndrome with portal hypertension (Table III). During his hospital stay he had repeated bouts of severe haematemesis for which he was operated upon. Exploration revealed that the liver was enlarged, congested, and spongy to feel. The inferior vena cava and the portal veins were dilated, with high pressure levels in both ( $27 \mathrm{~mm} \mathrm{Hg}$ each) hence portocaval shunt was not done and the splenic artery was ligated. Liver biopsy revealed changes suggestive of cirrhosis.

He was admitted for the last time five years later with a low-grade fever for a few days and repeated attacks of variceal bleeding. The clinical and bio- chemical findings were essentially the same as on the first admission. On the 19th day of admission had a severe haematemesis after which he died.

Necropsy showed a thin membrane in the inferior vena cava occluding its lumen just above the opening of the right hepatic vein which was patent. The liver was nodular in places. Microscopic examination showed a spectrum of histological lesions in different areas. Marked congestion and haemorrhages around the central veins were noted in some areas and cirrhosis in others. Some regenerating nodules showed signs of malignant change.

CASE 2

S.D., a 24-year-old housewife, was admitted with complaints of visible veins over the abdomen and flanks for over 10 years and two episodes of haematemesis in the last six days. There was no history of pain in the abdomen, jaundice, or febrile episodes. She had no children and had had menorrhagia for the last 13 years.

Physical examination revealed a well built woman of average nutrition. Prominent dilated, tortuous superficial veins were present over the abdomen and

\begin{tabular}{lccccc}
\hline Test & Case 1 & Case 2 & Case 3 & Case 4 & Case 5 \\
\hline Bromsulphthalein retention (\%) & 20 & 25 & 17 & $26-36$ & 29 \\
Total bilirubin (mg\%) & $0 \cdot 6$ & $1 \cdot 5$ & $0 \cdot 5$ & $0 \cdot 6$ & $0 \cdot 5$ \\
Alkaline phosphatase (King-Armstrong units) & $9 \cdot 2$ & $10 \cdot 4$ & $5 \cdot 0$ & $3 \cdot 4$ & $15 \cdot 0$ \\
Glutamic pyruvic transaminase (iu/litre) & $7 \cdot 1$ & $19 \cdot 0$ & $12 \cdot 0$ & $81-66 \cdot 5$ & $18 \cdot 0$ \\
Albumin (g\%) & $3 \cdot 2$ & $3 \cdot 0$ & $3 \cdot 2$ & $2 \cdot 5$ & $2 \cdot 3$ \\
Globulin (g\%) & $2 \cdot 3$ & $2 \cdot 7$ & $3 \cdot 0$ & $2 \cdot 5$ & $2 \cdot 2$ \\
Prothrombin time index (\%) & $59-72$ & 72.7 & 93 & 76 \\
Haemoglobin (g\%) & $4 \cdot 8$ & $8 \cdot 5$ & 14 & 10 & $6 \cdot 5$ \\
Total leucocyte count (per cmm) & 3600 & 4000 & 7000 & 7000 & 6000 \\
\hline
\end{tabular}

Table II Serum biochemical and haematological values at the time of presentation

\begin{tabular}{|c|c|c|c|c|c|c|c|c|c|c|c|c|c|c|}
\hline \multirow{2}{*}{$\begin{array}{l}\text { Case } \\
\text { No. }\end{array}$} & \multirow{2}{*}{$\begin{array}{l}\text { e Oeso- } \\
\text { phageal } \\
\text { Varices }\end{array}$} & \multicolumn{2}{|c|}{ Splenovenogram } & \multicolumn{2}{|c|}{$\begin{array}{l}\text { Percutaneous } \\
\text { Hepatogram }\end{array}$} & \multicolumn{2}{|c|}{$\begin{array}{l}\text { Inferior Vena Cava- } \\
\text { graphy }\end{array}$} & \multirow{2}{*}{$\begin{array}{l}\text { Intra- } \\
\text { splenic } \\
\text { Pressure }\end{array}$} & \multirow{2}{*}{$\begin{array}{l}\text { Superior } \\
\text { Vena Cava } \\
\text { Pressure }\end{array}$} & \multirow{2}{*}{$\begin{array}{l}\text { Right } \\
\text { Atrial } \\
\text { Pres- } \\
\text { sure }\end{array}$} & \multicolumn{2}{|c|}{$\begin{array}{l}\text { Inferior Vena } \\
\text { Cava Pressure }\end{array}$} & \multicolumn{2}{|c|}{ Hepatic Vein Pressure? } \\
\hline & & $\begin{array}{l}\text { Portal } \\
\text { Vein }\end{array}$ & $\begin{array}{l}\text { Colla- } \\
\text { terals }\end{array}$ & $\begin{array}{l}\text { Hepatic } \\
\text { Vein }\end{array}$ & $\begin{array}{l}\text { Inferior } \\
\text { Vena Cava }\end{array}$ & $\begin{array}{l}\text { Block at } \\
\text { Intra- } \\
\text { hepatic } \\
\text { Portion }\end{array}$ & $\begin{array}{l}\text { Hepatic } \\
\text { Vein }\end{array}$ & & & & $\begin{array}{l}\text { Below } \\
\text { Mem- } \\
\text { brane }\end{array}$ & $\begin{array}{l}\text { Above } \\
\text { Mem- } \\
\text { brane }\end{array}$ & Wedged & Free \\
\hline $\begin{array}{l}1 \\
2\end{array}$ & $\begin{array}{l}+ \\
+\end{array}$ & $\begin{array}{l}\text { Patent } \\
\text { Patent }\end{array}$ & + & $\begin{array}{l}\text { Not done } \\
\text { Dilated }\end{array}$ & $\begin{array}{l}\text { Retrograde } \\
\text { filled }\end{array}$ & $\begin{array}{l}\text { Not done } \\
+\end{array}$ & $\begin{array}{l}\text { Retrograde } \\
\text { filled, dilated }\end{array}$ & $\begin{array}{l}29 \\
23\end{array}$ & $\overline{4 \cdot 4}$ & $\begin{array}{l}5 \cdot 0 \\
5 \cdot 0\end{array}$ & $\begin{array}{l}27 \\
21\end{array}$ & $\begin{array}{l}5 \cdot 0 \\
5 \cdot 0\end{array}$ & $\begin{array}{l}\text { Not possible } \\
\text { Not possible }\end{array}$ & $\begin{array}{l}\text { Not possib } \\
\text { Not possib }\end{array}$ \\
\hline 3 & + & Patent & + & Dilated & $\begin{array}{l}\text { Retrograde } \\
\text { filled }\end{array}$ & + & $\begin{array}{l}\text { Retrograde } \\
\text { filled, dilated }\end{array}$ & 33 & $4 \cdot 0$ & $4 \cdot 0$ & 23 & $7 \cdot 7$ & $20 \cdot 7$ & $20 \cdot 7$ \\
\hline 4 & + & Patent & + & Not done & & + & $\begin{array}{l}\text { Not } \\
\text { visualized }\end{array}$ & 28 & $3 \cdot 5$ & $4 \cdot 0$ & 27 & $4 \cdot 0$ & $27 \cdot 0$ & $27 \cdot 0$ \\
\hline 5 & + & Patent & + & Dilated & $\begin{array}{l}\text { Retrograde } \\
\text { filled }\end{array}$ & + & $\begin{array}{l}\text { Retrograde } \\
\text { filled, dilated }\end{array}$ & 29 & $4 \cdot 0$ & $4 \cdot 0$ & 44 & $4 \cdot 0$ & $44 \cdot 0$ & $44 \cdot 0$ \\
\hline
\end{tabular}

Table III Radiological features and haemodynamic studies in the Budd-Chiari syndrome due to obstruction of intrahepatic portion of inferior vena cava

${ }^{1}$ All pressures are presented as mm of mercury and taken with a zero point $5 \mathrm{~cm}$ posterior to sternal angle with patient in supine position. 'Pressure above the membrance was recorded through the cubital route in cases $1,2,4$, and 5 ; however, as case 3 had partial membrane this could be recorded through the femoral route.

${ }^{2}$ Catheter could be wedged in main hepatic vein below the membrane through femoral route in three patients. 


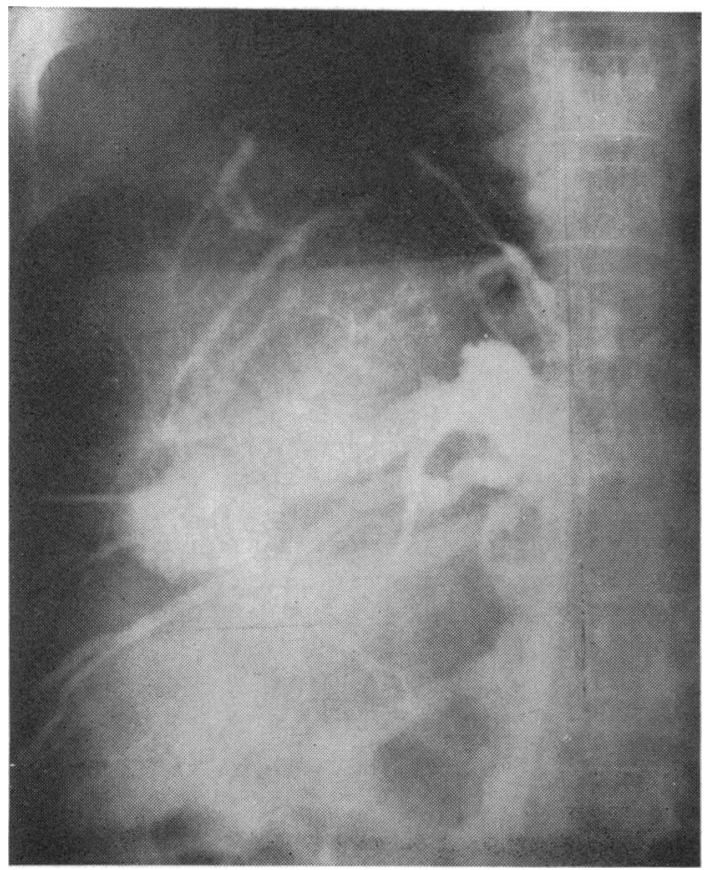

Fig. 1 Case 2. A percutaneous hepatograph. Note the dilated hepatic vein draining into the inferior vena cava. An obstruction at the upper end of the inferior vena cava is obvious.

the back with blood flow from below upwards. The liver which was enlarged by $3 \mathrm{~cm}$ below the costal margin, was firm and not tender. The spleen was also enlarged being palpable by $10 \mathrm{~cm}$ below the costal margin. There was no ascites.

Investigations gave normal results in liver function tests except for a high bromsulphthalein retention (Table II). Haemodynamic studies verified the portal hypertension and block in the intrahepatic portion of the inferior vena cava (Table III). Percutaneous hepatography revealed markedly dilated hepatic venous radicles draining into the inferior vena cava (Fig. 1). A cavogram of the vena cava showed a localized membrane a few millimetres thick obstructing the hepatic portion of the inferior vena cava (Fig. 2). Liver biopsy showed a dilated central vein with haemorrhage around it. There was no evidence of cirrhosis. She was offered surgery which she refused. She continues to be in good health and is being followed up.

\section{CASE 3}

D.S., a 27-year-old male teacher, came with com$3 *$

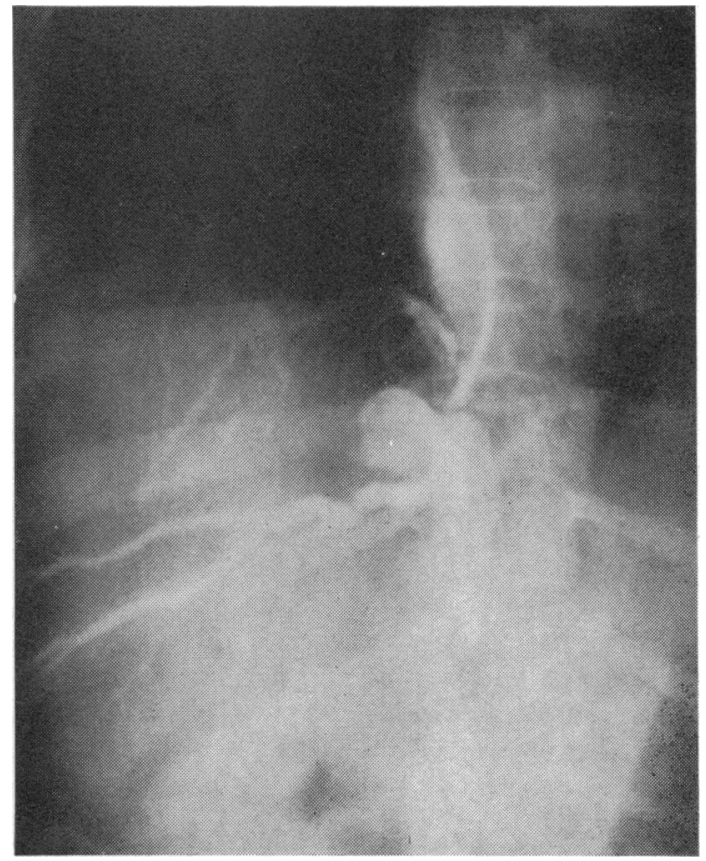

Fig. 2 Case 2. Cavogram showing a membrane-like obstruction in the intrahepatic segment of the inferior vena cava. The contrast was simultaneously injected from both the catheters.

discomfort for the last three years. There was no history of jaundice or haematemesis. Clinical examination revealed a healthy young man with firm, painless hepatomegaly of $4 \mathrm{~cm}$ and a just palpable spleen. Ascites was absent. There were inconspicuous superficial veins over the left and right lumbar region with the blood flow from below upwards. Liver function tests, except for bromsulphthalein retention, were essentially normal (Table II). Haemodynamic studies revealed a block in the intrahepatic portion of the inferior vena cava with portal hypertension (Table III). Percutaneous hepatography showed marked dilatation of the hepatic vein and retrograde visualization of the inferior vena cava with a block at the level of the tenth dorsal vertebra. Catheterizing by the femeral route an obstruction was encountered while manoevring the catheter along the lateral side of the inferior vena cava but it could negotiate the lumen along the medial side.

Lavography demonstrated a dome-shaped obstruction in the hepatic portion of the inferior vena cava with a retrograde flow of dye in the dilated hepatic vein.

Liver biopsy showed scattered haemorrhages in the hepatic parenchyma. There was no evidence of 
cirrhosis. Surgery was contemplated but the patient did not agree.

\section{CASE 4}

P.S., a 63-year-old farmer, began to be ill when he had haematemesis and melaena 20 years ago which was followed by marked pallor and recurrent attacks of pedal oedema and ascites. Since then he has been aware of hepatomegaly and prominent abdominal veins. He was treated with diuretics and had some relief. He had another episode of haematemesis two years ago and stood it well.

Physical examination revealed poor nutrition, pallor, pitting oedema, dilated and tortuous veins from the pelvis to the thorax with blood flow from below upward. The liver was palpable by $3 \mathrm{~cm}$ and the spleen by $5 \mathrm{~cm}$. Ascites was marked.

Liver function studies showed mild to moderate abnormalities (Table II). Haemodynamic and radiological investigations revealed a localized obstruction of the intrahepatic portion of the inferior vena cava with portal hypertension (Table III). He was treated conservatively and discharged after about six months in hospital.

\section{CASE 5}

B.S., a 45-year-old farmer, was admitted with complaints of gradual distension of the abdomen, oedema of the feet, and prominent abdominal veins for over two years preceded by mild pain in the epigastrium. There was a history suggestive of similar episodes 10 years before.

Physical examination revealed a pale, well built man

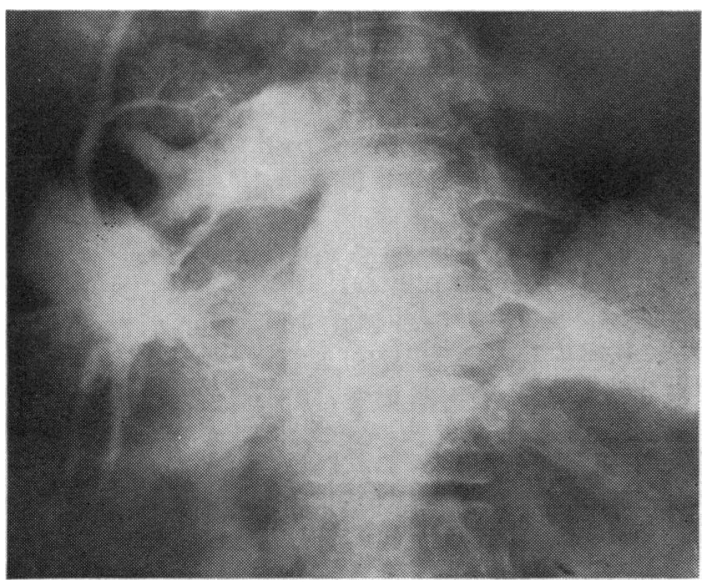

Fig. 3 Case 5. Percutaneous hepatograph. Note dilatation of hepatic veins and filling of inferior vena cava with a block at the upper end of the intrahepatic portion of the inferior vena cava. having tense ascites with oedema of the lower extremities. He also had prominent dilated, tortuous superficial veins all over the abdomen, chest, and back with blood flow from below upwards. The liver was palpable by $2 \mathrm{~cm}$, firm and painless, and the spleen by $2 \mathrm{~cm}$.

Liver function tests revealed no abnormality except for high bromsulphthalein retention (Table II). Haemodynamic and radiological investigations showed a thin membranous obstruction in the intrahepatic portion of the inferior vena cava with portal hypertension (Table III). Percutaneous hepatography and venography showed marked dilatation of hepatic veins and filling of the inferior vena cava with a block at the upper end of the intrahepatic portion of the inferior vena cava (Figs. 3 and 4). On liver biopsy changes were seen suggestive of cirrhosis with some sclerosis of a central vein and degeneration of cells around it. He was treated with diuretics and paracentesis with a favourable response. He sought admission a second time six months later with an episode of haematemesis for which he was conservatively treated.

\section{Discussion}

The occurrence of the Budd-Chiari syndrome due to an obstructive lesion of small or large radicles of hepatic veins or of the inferior vena cava at or above the site of the opening of the hepatic veins is well recognized. Although cases with hepatic vein obstruction have been well documented, the importance of lesions of the inferior vena cava producing

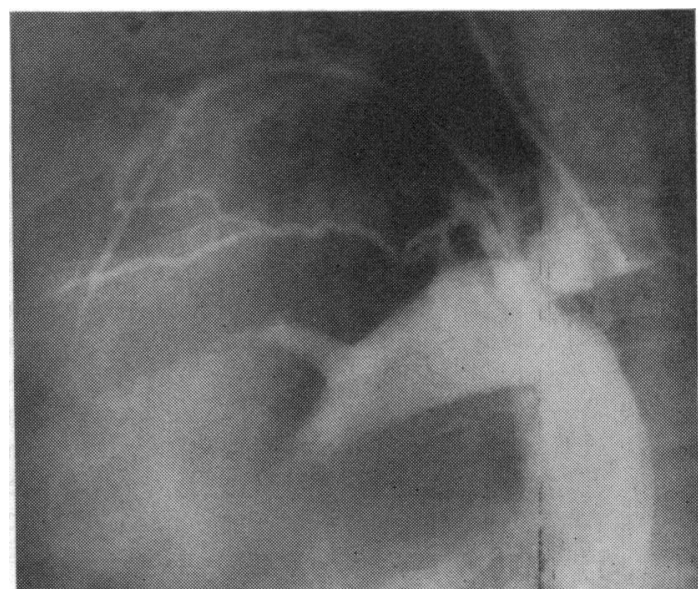

Fig. 4 Case 5. Cavogram showing a localized obstruction of the intrahepatic portion of the inferior vena cava with retrograde filling of a dilated hepatic vein. The contrast was simultaneously injected from both the catheters. 
this syndrome has only recently been realized. With progress in the techniques of venous catheterization and hepatography it is possible to some extent to localize the primary site of obstruction (Clain, Freston, Kreel, and Sherlock, 1967). The precise site and extent of obstruction of the inferior vena cava can be evaluated by simultaneous catheterization from the antecubital and saphenous veins. Hepatography may help in the localization of obstruction in the hepatic veins as reported earlier (Clain et al, 1967) and even in the inferior vena cava as shown here. In fact the diagnosis of the Budd-Chiari syndrome today should appropriately be qualified as due to obstruction of the main hepatic veins, obstruction of the hepatic portion of the inferior vena cava (partial or complete), or both. As the isolated obstructive lesions of the inferior vena cava in the hepatic portion have been found to be amenable to surgery with encouraging results (Yamamoto et al, 1968), the recognition of the appropriate site of obstruction is of great practical importance. The wide clinical spectrum and natural history of such cases have been reviewed by Nakamura et al (1968).

It will be recalled that although such cases are reported to be the predominant cause of the BuddChiari syndrome in Japan (Nakamura et al, 1968), similar isolated cases have been reported from America (Bennett, 1950; Watkins and Fortin, 1964; Lam, Green, and Gale, 1965; Schaffner, Gadboys, Safran, Baron, and Aufses, 1967; Davis, Peters, and Reynold, 1968), England (Hepner, Steiner, and Bentall, 1969), India (Bhale Rao, Personal communication), Africa (Rogers, Chesler, Du Plessis, Joffe, and Joubert, 1967), and New Zealand (Smith, 1965). It is of interest that five of our 11 patients had the clinical, radiological, and haemodynamic similarity to the cases described as membranous obstruction of the inferior vena cava in the hepatic portion (Kimura et al, 1963). One of the patients (case 3) corresponds with 'type A', partial obstruction, and the rest belong to 'type B', complete membranous obstruction of the inferior vena cava as described by Yamamoto et al (1968). It is likely, therefore, that the greater awareness of the syndrome, coupled with the applicability of improved techniques of investigation, might reveal that such patients are not exclusive to any particular geographical distribution but may have a worldwide occurrence.

The cause of the localized obstruction in the intrahepatic portion of the inferior vena cava is unknown. Kimura et al (1963) thought it was a congenital developmental anomaly related to the closure of the ductus venosus. Rossall and Caldwell (1957) and Kibel and Marsden (1950) attribute it to a persistent eustachian valve. If the lesions are congenital in origin the delayed appearance of clinical mani- festations would probably indicate a deterioration in the compensating collateral circulation or a superadded thrombosis. The possibility of this localized obstruction being an acquired lesion cannot be easily excluded during life. In this context it may be recalled that some narrowing of the inferior vena cava by radiological investigation can be demonstrated in patients with the classical Budd-Chiari syndrome due to hepatic vein obstruction with or without cirrhosis (Clain et al, 1967).

The diagnosis of inferior vena cava obstruction should be considered in all cases of the Budd-Chiari syndrome even without obvious signs, as such patients without visible or significant abdominal venous collaterals have been reported (Davis et al, 1968; Yamamoto et al, 1968). This point has been well illustrated in our case 3 where visible abdominal venous collaterals were insignificant yet the hepatography and vena caval catheterization showed an obstruction in the inferior vena cava.

Clain and his colleagues (1967) for the first time used the technique of hepatography for the diagnosis of hepatic vein occlusion. The present report amply demonstrated its additional value in the diagnosis of the obliteration of the intrahepatic portion of the inferior vena cava as well. The significance of the diagnosis in such patients, as already emphasized, is not only because of the correctable nature of the lesion but for the prognosis as well. The long survival of untreated patients appears to be the rule. Four of the five patients in the present series are living after three years to 20 years of illness in contrast to five of the six patients with hepatic vein occlusion who died within two years of diagnosis.

We wish to thank Professor P. L. Wahi for referring one patient (case 2) to us and to Hospital Photographic Department (Mr Sekhon and Mr Kohli) for their advice and assistance. Part of this work was carried out under a grant from the Indian Council of Medical Research.

\footnotetext{
References

Atkinson, M., and Sherlock, S. (1954). Intrasplenic pressure as an index of portal venous pressure. Lancet, 1, 1325-1327.

Bennett, I. L., Jr. (1950). A unique case of obstruction of the inferior vena cava. Bull. Johns Hopk. Hosp., 87, 290-298.

Bhale Rao, R. A., in discussion on a paper by Datta, D. V., Saha, S., Samanta A.Singh, Gupta, B. B., Aikat, B. K., and Chhuttani, P. N. (1971). Budd-Chiari syndrome due to a membranous obstruction of intra-hepatic portion of inferior vena cava. Hitherto unrecognized syndrome in India. Proceedings of the Indian Society of Gastroenterology (1845). On Diseases of the Liver. Churchill, London.

Budd, G., Quoted by Parker, R. G. F. (1959).

Chiari, H. (1899). Ueben die selbständige Phlebitis Obliterans der Hauptstämme der Venae hepaticae alo Todesursache. Beitr. path. Anat., 26, 1. Quoted by Parker, R. G. F. (1959).

Clain, D., Freston, J., Kreel, L., and Sherlock, S. (1967). Clinical diagnosis of Budd-Chiari syndrome. Amer. J. Med., 43, 544554.
} 
Davis, M., Peters, R., and Reynolds, T. (1968). Budd-Chiari syndrome due to inferior vena cava obstruction. Gastroenterology, 54, 1142-1147.

Hepner, G. W., Steiner, R. E., and Bentall, H. H. (1969). Hepatic venous occlusion associated with intrahepatic narrowing of the inferior vena cava. Brit. J. Surg., 56, 245-250.

Kibel, M. A., and Marsden, H. B. (1956). Inferior vena caval and hepatic vein thrombosis; the Chiari syndrome in childhood. Arch. Dis. Child., 31, 225-228.

King, E. J., and Wootton, I. D. P. (1959). Micro-analysis in Medical Biochemistry, 3rd ed. Churchill, London.

Kimura, C., Shirotani, H., Hirooka, M., Terada, M., Iwahashi, K., and Maetani, S. (1963). Membranous obliteration of the inferior vena cava in the hepatic portion. J. cardiovasc. Surg., 4, 87-98.

Lam, C. R., Green, E., and Gale, H. (1965). Transcardiac membranotomy for obstruction of the hepatic portion of the inferior vena cava. Circulation, Suppl. 1, 31-2, 188-191.

Moreno, A. H., Ruzicka, F. F., Rousselot, L. M., Burehell, A. R. Bone, R. F., Slafsky, S. F., and Burke, J. H. (1963). Functional hepatography. A study of the hemodynamics of the outflow tracts of the human liver by intraparenchymal deposition of contrast medium, with attempts at functional evaluation of the outflow block concept of cirrhotic ascites and the accessory outflow role of the portal vein. Radiology, 81, 65-79.

Nakamura, T., Nakamura, S., Aikawa, T., Suzuki, O., Onodera, A., and Karoji, N. (1968). Obstruction of the inferior vena cava in the hepatic portion and the hepatic veins. Angiology, 19, 479498.

Nishikawa, Y. (1918). Ueber die obliteration der Stammlebervenen und des heparen Hohlvenenabschnittes. Mitt. med. Fak. Tokyo, 20, 151-305.

Parker, R. G. F. (1959). Occlusion of the hepatic veins in man. Medicine (Baltimore), 38, 369-402.

Rogers, M. A., Chesler, E., Du Plessis, L., Joffe, N., and Joubert, E. (1967). Membranous obstruction of the hepatic segment of the inferior vena cava. Brit. J. Surg., 54, 221-225.

Rossall, R. E., and Caldwell, R. A. (1957). Obstruction of inferior vena cava by a persistent Eustachian valve in a young adult. J. clin. Path., 10, 40-45.

Schaffner, F., Gadboys, H. L., Safran, A. P., Baron, M. G., and Aufses, A. H., Jr. (1967). Budd-Chiari syndrome caused by a web in the inferior vena cava. Amer. J. Med., 42, 838-843.

Smith, L. (1965). A case of congenital stenosis of the inferior vena cava with portal hypertension. Brit. J. Surg., 52, 913-916.

Sherlock, S. (1968). Diseases of Liver and Biliary System, 4th ed. Blackwell, Oxford.

Watkins, E., Jr., and Fortin, C. L. (1964). Surgical correction of congenital coarctation of the inferior vena cava. Ann. Surg., 159, 536-541.

Yamamoto, S., Yokoyama, Y., Takeshige, K., and Iwatsuki, S. (1968). Budd-Chiari syndrome with obstruction of the inferior vena cava. Gastroenterology, 54, 1070-1084.

\section{The April 1972 Issue}

\section{THE APRIL 1972 ISSUE CONTAINS THE FOLLOWING PAPERS}

Aspects of duodeno-gastric reflux in man $\mathrm{K}$. G. WORMSLEY

Gastric acid barrier to ingested microorganisms in man: studies in vivo and in vitro R. A. GIANNELLA, S. A. BROITMAN, AND N. ZAMCHECK

Granulomatous arthritis in Crohn's disease c. LINDSTRÖM, H. WRAMSBY, AND G. ÖSTBERG

Pathology of intestinal tuberculosis and its distinction from Crohn's disease H. D. TANDON AND A. PRAKASH

A study of six patients with hypertrophy of the gastric mucosa with particular reference to albumin metabolism E. A. JONES, W. B. YOUNG, B. C. MORSON, AND A. M. DAWSON

Acetylator phenotype and adverse effects of sulAND DAVID A. PRICE EVANS phasalazine in healthy subjects HASSE SCHRÖDER

Effect of oral hypoglycaemic agents on glucose tolerance in pancreatic diabetes B. I. JOFFE, W. P. U. JACKSON, S. BANK, AND A. I. VINIK

Partial nodular transformation of the liver presenting with ascites A. P. DICK AND G. A. GRESHAM

The effect of octapressin on renal and intrarenal blood flow in cirrhosis of the liver M. C. KEW, R. R. VARMA, D. J. SAMPSON, AND SHEILA SHERLOCK

Progress report Long-incubatin (virus B, HAAassociated) hepatitis SHEILA SHERLOCK

Progress report The control of pancreatic secretion A. A. HARPER

The British Society of Gastroenterology

British Society for Digestive Endoscopy

Notes and activities

Copies are still available and may be obtained from the PUBLISHING MANAGER,

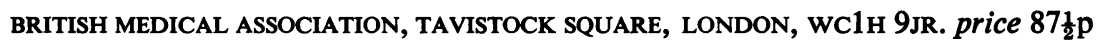

